\title{
PENGARUH PEMBERIAN JUS MENTIMUN TERHADAP PENURUNAN TEKANAN DARAH LANSIA HIPERTENSI
}

\author{
Sri Lestari*, Dini Siti nuraeni**
}

\begin{abstract}
ABSTRAK
Pemberian jus mentimun adalah salah satu pengobatan herbal yang memiliki beberapa kelebihan, antara lain efek samping yang relatif rendah, dalam suatu ramuan dengan komponen berbeda serta memiliki lebih dari satu efek farmakologi saling mendukung serta sesuai untuk penyakit-penyakit metabolik dan degeneratfi seperti hipertensi. Jenis penelitian ini adalah Quasy Exsperimen,rancangan ini berupaya mengungkapkan hubungan sebab akibat dengan cara melibatkan kelompok kontrol di samping kelompok intervensi. Sampel yang di tentukan 30 responden yang di bagi menjadi 2 kelompok intervensi dan kelompok dianalisis menggunakan uji wilcoxon. Metode Pengumpulan Data dengan Pemeriksaan dan instrumen menggunakan spigmomanometer. Hasil penelitian dari 30 responden menunjukan responden yang di berikan jus mentimun yang di lakukan selama 30 hari dengan takaran $100 \mathrm{cc}$ mengalami penurunan sebesar 34,00 mmHg pada sistol dan 4,67 mm/Hg pada tekanan diastol. Sedangkan pada kelompok kontrol menunjukan adanya peningkatan tekanan sistol sebesar $2,67 \mathrm{mmHg}$ dan tekanan diastolnya menunjukan tidak ada perubahan. Uji statistik dengan t.test di dapatkan $p$ value 0,850 lebih dari alpha 0,005 sehingga dapat di simpulkan gagal penolakan terhadap hipotesis.
\end{abstract}

Kata kunci : Hipertensi, Lansia, Mentimun.

\section{ABSTRACT}

Giving cucumber juice is one of the herbal remedies that have several advantages, such as relatively low side effects, in an herb with different components as well as having more than one pharmacological effects of mutual support and appropriate for metabolic diseases such as hypertension and degeneratif. The purpose of this study was to determine the effect before and after the administration of cucumber juice in elderly hypertensive.

This research is Quasy Exsperimen, this design seeks to reveal the causal relationship by engaging with the control group in addition to the intervention group. Samples were determined in 30 respondents were divided into 2 groups of intervention and control groups in the analysis then uses wilxocon test. Data collection methods and instruments used by the Examination spigmomanometer. The results of the 30 respondents to the univariate test results show that the respondent is given juice cucumbers are done every day for 30 days to provide as much as 100 cc cucumber juice decreased by $34.1 \mathrm{mmHg}$ in systolic and $4.67 \mathrm{mmHg}$ diastolic pressure. While the group is not given the intervention showed an increase in systolic pressure of $2.67 \mathrm{mmHg}$ and pressure diastolnya showed no change. Statistical test with $\mathrm{p}$ value T.test in get .850 over 0,005 alpha can be concluded that the rejection of the hypothesis fails. Keywords : Hypertension, Elderly, Cucumber.

\footnotetext{
* Staf Pengajar Program Studi S1 Keperawatan STIKes Cirebon

**Alumni PSIK STIKes Cirebon Lulus Tahun 2014
} 


\section{PENDAHULUAN}

Usia lanjut atau menua adalah kejadian yang alami, jadi tidak dapat dihindari, pada masa ini pentingnya mencegah adalah untuk mengusahakan agar fungsi-fungsi tubuh dapat di pertahankan selama mungkin dan mencegah sejauh mungkin penyakit-penyakit yang mudah timbul akibat terjadinya penuaan, sebab lansia seringkali meninggal dunia bukan karna di sebabkan usianya tetapi karna penyakit yang di deritanya. ${ }^{1}$

Masalah kesehatan lansia sangat bervariasi, selain erat kaitannya dengan degenaratif, juga secara progresif. Karena menua adalah suatu proses menghilangnya secara perlahan-perlahan kemampuan jaringan untuk memperbaiki diri / mengganti diri dan mempertahankan struktur dan fungsi normalnya sehingga tidak dapat bertahan terhadap jejas (termasuk infeksi) dan memperbaiki kerusakan yang diderita. Dengan begitu manusia secara progresif akan kehilangan daya tahan terhadap infeksi dan akan menumpuk makin banyak distorsi metabolic dan struktural yang disebut sebagai penyakit degeneratif. ${ }^{2}$

Penyakit degeneratif adalah penyakit yang mengiringi proses penuaan, penyakit ini terjadi seiring bertambahnya usia. Penyakit degeneratif merupakan istilah yang secara medis digunakan untuk menerangkan adanya suatu proses kemunduran fungsi sel saraf tanpa sebab yang diketahui, yaitu dari keadaan normal sebelumnya ke keadaan yang lebih buruk. Penyakit yang termasuk dalam kelompok ini diantaranya adalah Diabetes Melitus Type II, Stroke, Hiperkolesterolemia, Penyakit Kardiovaskular, Hipertensi. ${ }^{3}$

Hipertensi erat kaitannya dengan gangguan kardiovaskuler,dengan tekanan darah yang sangat tinggi besar kemungkinan akan menimbulkan penyakit yang lain seperti stroke, gagal ginjal, dan serangan jantung. Hipertensi adalah penyakit yang sangat sulit untuk identifikasi oleh sebab itu hipertensi di juluki dengan pembunuh diam-diam atau silent killer. ${ }^{4}$

Prevalensi penderita hipertensi di Indonesia cukup tinggi, yaitu 83 per 1.000 anggota rumah tangga dan $65 \%$ nya merupakan orang yang telah berusia 55 tahun ke atas. ${ }^{5}$ Proporsi kasus tidak menular di Kota Cirebon, tahun 2008 berdasarkan hasil RISKESDAS (Riset Kesehatan Dasar ), Hipertensi dan Stroke menepati urutan kedua kedua dan ketiga dengan jumlah kumulatif 21,6 \%. Pola penyakit penyebab kematian pasien rawat inap di RTumah Sakit pada kelompok umur 45-64 tahun, hipertensi menduduki urutan ke 7, sedangkan pada kelompok umur lebih dari 66 tahun , hipertensi menduduki urutan ke 4. Tetapi bila melihat urutan pertama penyebab kematian adalah infark dan dekompensasib kordis dan kedua pernyakit ini merupakan komplikasi/ berhubungan dengan hipertensI. ${ }^{6}$

Mahalnya harga obat sering menjadi kendala dalam penanganan kasus ini mengingat jangka waktu terapi yang relatif lama mengakibatkan biaya yang diperlukan pun relatif tidak sedikit. Penggunaan obat antihipertensi sebenarnya dapat dihindari dengan cara pencegahan dan penanggulangan hipertensi yang dilakukan sejak dini. ${ }^{5}$

Kalium yang terdapat dalam mentimun terdapat kaitan dengan regulasi tekanan darah, kalium dapat menurunkan tekanan darah dengan menimbulkan efek vasodilatasi sehingga menyebabkan penurunan retensi perifer total dan meningkatkan output jantung. Konsumsi kalium yang banyak akan meningkatkan konsentrasinya di dalam cairan intraseluler sehingga cenderung menarik cairan dari bagian ekstraseluler dan menurunkan tekanan darah. ${ }^{7}$

Dibandingkan obat-obat modern, pengobatan herbal memiliki beberapa kelebihan, antara lain efek samping yang relatif rendah, dalam suatu ramuan dengan komponen berbeda memiliki efek saling mendukung, pada satu tanaman memiliki lebih dari satu efek farmakologi serta lebih sesuai untuk penyakit-penyakit metabolik dan degeneratif. ${ }^{8}$

Dari penelitian sebelumnya yang dilakukan oleh Zauhani Kusnu dan Zainal Munir dengan judul pengaruh pemberian jus mentimun pada penderita tekanan darah tinggi oleh yang dilaksanakan di UPT PSLU (Unit Pelayanan Terpadu, Pelayanan Sosial Lanjut Usia) Jombang, STIKes Bahrul Ulum menunjukkan bahwa terbukti secara empiris ada efek bermakna dari pemberian jus mentimun pada penurunan tekanan darah, hal ini dimungkinkan karena 
mentimun mengandung potasium (kalium), magnesium, dan fosfor, dimana mineral-mineral tersebut efektif mampu mengobati hipertensi. ${ }^{9}$

Pada lansia penurunan fungsi fisiologis pada rongga mulut akan mempengaruhi proses mekanisme makanan, banyaknya gigi yang tanggal serta terjadi kerusakan gusi karena proses degenerasi, kedua hal ini sangat mempengaruhi proses pengunyahan makanan. Lansia akan kesulitan untuk mengkonsumsi makanan yang konsistensinya keras oleh karen itu peneliti akan memudahkan cara pemberian mentimun dengan cara mengubahnya dalam bentuk jus namun tidak di berikan tambahan bahan lainnya. ${ }^{10}$ Tujuan penelitian ini adalah untuk mengetahui pengaruh pemberian jus mentimun terhadap penurunan tekanan darah lansia hipertensi di wilayah kerja UPTD Puskesmas Sunyaragi.

\section{METODE PENELITIAN}

Penelitian yang digunakan peneliti adalah eksperimen semu atau quasi experiment with control group. Rancangan penelitian ini di menggunakan rancangan pretest dan postest dengan kelompok kontrol. peneliti melakukan pretest (01) pada kedua kelompok tersebut dan di ikuti intervensi (X) yaitu pemberian jus mentimun pada kelompok eksperimen setelah beberapa waktu di lakukan postest (02) pada kedua kelompok tersebut.

Populasi dalam penelitian ini sebanyak 172 lansia dengan 72 lansia penderita hipertensi di wilayah kerja UPTD Puskesmas Sunyaragi Kota Cirebon. Pengambilan sampel dalam penelitian ini adalah dengan menggunakan Purposive sampling dengan kriteria sebagai berikut : ${ }^{11}$

1. Lansia yang berumur $>45$ tahun.

2. Tidak mengkonsumsi obat medis.

3. Lansia yang terdiagnosa hipertensi tanpa adanya komplikasi penyakit lain.

4. Lansia yang bertempat tinggal di wilayah Sunyaragi Kota Cirebon.

5. Lansia yang bersedia untuk di jadikan responden penelitian.

Sampel yang di dapatkan peneliti di wilayah kerja UPTD Puskesmas Sunyaragi sebanyak 30 orang dari 72 lansia penderita hipertensi .

Instrumen yang di gunakan adalah spigmomanometer untuk mengukur tekanan darah pada lansia, pengukuran tekanan darah lansia mengacu pada Canadian Hypertension Education Program (CHEP, 2009) di lakukan pengukuran minimal 3 kali pada posisi duduk dengan jarak minimal 1 menit, pengukuran pertama di abaikan, kemudian di ambil rata-rata dari dua pengukuran selanjutnya. Pada usia lanjut terdapat berbagai keadaan yang sering menjadi masalah dalam menentukan tekanan darah. ${ }^{12}$

Analisa data terdiri dari Analisis univariat bertujuan untuk menjelaskan atau mendeskripsikan karakteristik setiap variabel penelitian. Sedangkan analisis bivariat untuk mengetahui pengaruh pemberian jus mentimun terhadap penurunan tekanan darah pada lansia hipertensi, yaitu menggunakan uji $\mathrm{T}$ (T-test) dengan batas kemaknaan (nilai alpha) 5\%. Untuk melihat hasil kemaknaan perhitungan statistik digunakan batas kemaknaan 0,05. Penolakan terhadap hipotesis apabila $\mathrm{P}$ value $\leq 0,05$ berarti ada pengaruh atau ada perbedaan makna, sedangkan gagal penolakan terhadap hipotesis apabila $\mathrm{P}$ value $>0,05$ berarti tidak ada pengaruh atau perbedaan yang bermakna antara keduanya

\section{HASIL PENELITIAN DAN PEMBAHASAN}

\section{Tekanan Darah Sebelum Intervensi}

Pada kelompok intervensi sebelum di berikan jus mentimun, responden berada pada hipertensi tahap 1 sebanyak 4 orang dan hipertensi tahap 2 sebanyak 11 orang dengan rata-rata tekanan darah pada kelompok sistol $165,33 \mathrm{mmHg}$ sedangkan pada tekanan diastol rata-rata tekanan darah 98,00 mmhg.

Pada kelompok kontrol di dapatkan sampel responden dalam kondisi hipertensi tahap 1 sebanyak 1 orang dan hipertensi tahap 2 sebanyak 14 orang, tekanan darah sistol dengan rata-rata $170 \mathrm{mmHg}$ sedangkan rata-rata tekanan darah diastol $95,33 \mathrm{mmHg}$. 


\section{Tekanan Darah Setelah Intervensi}

Data yang di dapatkan setelah pemberian jus mentimun selama 30 hari sebanyak $100 \mathrm{cc}$ pada kelompok yang di berikan/kelompok intervensi yang mengalami prehipertensi sebanyak 12 orang dan hipertensi tahap 1 menjadi 3 orang. Rata-rata tekanan darah sistol 131,33 $\mathrm{mmHg}$ sedangakan rata-rata tekanan darah diastol sebesar $93,33 \mathrm{mmHg}$.

Pada kelompok kontrol yang tidak di berikan terapi jus mentimun mengalami kondisi hipertensi tahap 2 sebanyak 15 orang, Rata-rata tekanan darah kelompok sistol 172,17 mmHg, median sedangkan rata-rata tekanan darah diastol $95,33 \mathrm{mmHg}$.

\section{Pengaruh Pemberian Jus mentimun terhadap Penurunan Tekanan Darah.}

Tabel 1 Rata-rata penurunan tekanan darah sistol pada kelompok intervensi dan kelompok kontrol.

\begin{tabular}{lllll} 
& $\mathrm{N}$ & Mean & $\mathrm{Sd}$ & $\mathrm{Se}$ \\
\hline intervensi & 15 & 34,00 & 7,368 & 1,902 \\
\hline kontrol & 15 & $-2,67$ & 7,988 & 2,063 \\
\hline
\end{tabular}

Tabel 2 Rata-rata penurunan tekanan darah diastol pada kelompok intervensi dan kelompok kontrol.

\begin{tabular}{lllll}
\hline & $\mathrm{N}$ & Mean & $\mathrm{Sd}$ & $\mathrm{Se}$ \\
\hline intervensi & 15 & 4,67 & 6,399 & 1,652 \\
\hline kontrol & 15 & 0,00 & 0,000 & 0,000 \\
\hline
\end{tabular}

Dari hasil uji statistik di dapatkan adanya penurunan tekanan darah sistol pada kelompok intervensi dengan rata-rata penurunan $34,00 \mathrm{mmHg}$ sedangkan tekanan darah diastole rata-rata penurunan 4,67 mmhg dan pada kelompok kontrol terdapat rata-rata kenaikan pada kelompok sistol sebesar 2,67 mmHg sedangkan rata-rata tekanan darah diastole tidak ada perubahan.

\section{PEMBAHASAN}

\section{Tekanan darah sebelum perlakuan.}

Berdasarkan penelitian yang telah dilakuakan pada lansia penderita hipertensi di Wilayah Kerja UPTD Puskesmas Sunyaragi Kota Cirebon sebelum di berikan terapi jus mentimun. Pada tekanan sistol kelompok intervensi di dapatkan rata rata tekanan darah sebesar $165,33 \mathrm{mmHg}$, tekanan diastole 98,00 mmhg pada kelompok kontrol tekanan sistol di dapatkan rata-rata tekanan darah $170,00 \mathrm{mmHg}$ dan rata-rata tekanan diastole $95,33 \mathrm{mmhg}$.

Hipertensi erat kaitannya dengan gangguan kardiovaskuler,dengan tekanan darah yang sangat tinggi besar kemungkinan akan menimbulkan penyakit yang lain seperti stroke, gagal ginjal, dan serangan jantung. Hipertensi adalah penyakit yang sangat sulit untuk identifikasi oleh sebab itu hipertensi di juluki dengan pembunuh diam-diam atau silent killer. ${ }^{4}$

Pada lansia mekanisme dasar peningkatan sistolik akan terjadinya penurunan elastisitas dan meregang pada arteri besar. Tekanan aorta meningkat sangat tinggi dengan penambahan volume intavaskuler yang sedikit menunjukan kekakuan pembuluh darah pada usia lanjut. Secara hemodinamik hipertensi sistolik di tandai dengan penurunan kelenturan pembuluh arteri besar resistensi feriper yang tinggi, pengisian diastolic yang abnormal dan bertambahnya masa ventrikel kiri. Penurunan volume darah dan output jantung disertai dengan kekakuan arteri besar menyebabkan penurunan tekanan diastolic. Perubahan aktifitas sistim saraf simpatis dengan bertambahnya nerophineprin menyebabkan penurunan tingkat kepekaan sistim reseptor beta adregenik sehingga berakibat penurunan fungsi relaksasi otot pembuluh darah lanjut usia mengalami kerusakan stuktural dan fungsional pada arteri besar yang membawa darah dari jantung menyebabkan semakin parahnya pengerasan pembuluh darah dan tingginya tekanan darah. ${ }^{13}$ 


\section{Tekanan Darah sesudah perlakuan}

Berdasarkan penelitian yang di lakukan pada lansia hipertensi di UPTD Puskesmas Sunyaragi Kota Cirebon didapatkan rata rata tekanan darah sistol pada kelompok intervensi sebesar 131,33 $\mathrm{mmHg}$ sedangkan tekanan diastol di dapatkan rata-rata tekanan darah sebesar 93,33 $\mathrm{mmHg}$ dan tekanan darah sistol pada kelompok kontrol di dapatkan rata-rata 172,67 mmHgsedangkan tekanan darah diastol rata-rata tekanan darah sebesar 95,33 $\mathrm{mmHg}$.

Pasien yang menderita hipertensi di sarankan untuk mengkonsumsi mentimun, mentimun dapat mengobati hipertensi karena kandungan mineralnya yaitu potassium, magnesium, dan fosfor selain itu mentimun bersifat diuretik karena kandungan airnya yang sangat tinggi hingga membantu menurunkan tekanan darah . akar dan buah mentimun juga memiliki kandungan alkaloida , polifenol, dan saponin. ${ }^{14}$

Konsumsi kalium dalam jumlah yang tinggi dapat melindungi individu dari hipertensi. Asupan kalium yang meningkat akan menurunkan tekanan darah sistolik dan diastolik ,penderita hipertensi sangat disarankan untuk mengkonsumsi mentimun, karena kandungan mineral kalium, magnesium, dan serat di dalam timun bermanfaat untuk menurunkan tekanan darah. Serta mineral magnesium yang juga berperan melancarkan aliran darah dan menenangkan saraf. ${ }^{15}$

\section{Pengaruh pemberian jus mentimun terhadap penurunan tekanan darah}

Hasil penelitian menunjukkan tidak ada pengaruh pemberian jus mentimun terhadap terhadap penurunan tekanan darah. Berbeda dengan hasil penelitian Zauhani Kusnu dan Zainal Munir yang dilaksanakan di UPT PSLU (Unit Pelayanan Terpadu, Pelayanan Sosial Lanjut Usia) Jombang, STIKes Bahrul Ulum menunjukkan bahwa terbukti secara empiris ada efek bermakna dari pemberian jus mentimun pada penurunan tekanan darah, hal ini dimungkinkan karena mentimun mengandung potasium (kalium), magnesium, dan fosfor, dimana mineral-mineral tersebut efektif mampu mengobati hipertensi. ${ }^{9}$

Kandungan air pada mentimun yang tinggi berfungsi menurunkan tekanan darah dengan berkhasiat sebagai diuretik. Air mentimun juga menjaga kesehatan ginjal dan aktivitasnya sehingga dapat mengubah aktivitas sistem renin-angiotensin. Kandungan kalium (potasium) membantu mengatur saraf perifer dan sentral yang mempengaruhi tekanan darah. Cara kerja kalium berbeda dengan natrium, kalium (potasium) merupakan ion utama di dalam cairan intraseluler. Cara kerja kalium adalah kebalikan dari natrium. Konsumsi kalium yang banyak akan meningkatkan konsentrasinya di dalam cairan intraseluler sehingga cenderung menarik cairan dari bagian ekstraseluler dan menurunkan tekanan darah. ${ }^{7}$

Konsumsi kalium dalam jumlah yang tinggi dapat melindungi individu dari hipertensi. Asupan kalium yang meningkat akan menurunkan tekanan darah sistolik dan diastolik ,penderita hipertensi sangat disarankan untuk mengkonsumsi mentimun, karena kandungan mineral kalium, magnesium, dan serat di dalam timun bermanfaat untuk menurunkan tekanan darah. Serta mineral magnesium yang juga berperan melancarkan aliran darah dan menenangkan saraf. ${ }^{15}$

\section{SIMPULAN}

1. Sebelum di berikan jus mentimun.

Tekanan darah kelompok intervensi dan kelompok kontrol sebelum di berikan jus mentimun, pada kelompok intervensi di dapatkan rata-rata tekanan darah sistol sebesar 165,33 $\mathrm{mmHg}$ dan tekanan diastol sebesar 98,00 $\mathrm{mmHg}$, Sedangkan pada kelompok kontrol rata-rata tekanan darah sistol 170,00 mmHg dan diastol 95,33 mmHg.

2. Setelah di berikan jus mentimun.

Rata-rata tekanan darah kelompok intervensi dan kelompok kontrol setelah di berikan jus mentimun. Pada kelompok intervensi rata-rata tekanan darah sistol 131,33 $\mathrm{mmHg}$ dan tekanan diastol sebesar 93,33 mmHg sedangkan pada kelompok kontrol rata-rata tekanan darah yang di hasilkan 172,67 mmHg pada sistol dan $95,33 \mathrm{mmHg}$ pada tekanan diastolnya.

3. Pengaruh pemberian jus mentimun terhadap tekanan darah. 
Pengaruh penurunan tekanan darah kelompok intervensi dan kelompok kontrol menunjukan bahwa kelompok intervensi terjadi penurunan tekanan darah baik sistol maupun distol di bandingkan dengan kelompok kontrol, pada kelompok intervensi di dapatkan penurunan tekanan darah sistol sebesar 34,1 mmHg dan pada tekanan darah diastol di dapatkan penurunan tekanan darah sebesar 4,67 mmHg sedangkan pada kelompok kontrol terjadi kenaikan tekanan darah sistol sebesar 2,67 mmHg dan tidak mengalami perubahan pada kelompok diastol.

\section{SARAN}

1. Bagi Masyarakat

Bagi keluarga dan responden hasil penelitian ini merupakan informasi dan pengetahuan tentang pengobatan tradisional bagi yang berkepentingan dalam upaya menurunkan tekanan darah pada lansia hipertensi.

2. Bagi keperawatan.

Diharapkan penelitian ini dapat memberikan masukan bagi profesi keperawatan dalam mengembangkan keperawatan lansia dengan hipertensi.

\section{DAFTAR PUSTAKA}

1. Arisman. Gizi dalam Daur Kehidupan.EGC:Jakarta;2004

2. Nasotion, Andi hakim dan Karyadi, Darwin.Gizi untuk Kebutuhan Fisiologis Khusus, Jakarta: PT.Gramedia; 1988

3. Muchtadi, D. Sayuran sebagai sumber serat pangan untuk mencegah timbulnya penyakit degeneratif. Jakarta:PT Gramedia;2001

4. Dewi. S \& Familia. D .Hidup bahagia dengan hipertensi. Jogjakarta:A.Plus;2010

5. Anonim. Hipertensi.[diakses tanggal 23 Februari 2012]. Diunduh dari; www.depkes.go.id

6. Yati Mulyati. Sri. Hubungan Pengetahuan Dengan Kepatuhan Program Pengobatan Pada penderita Hipertensi Di Puskesmas Kesambi Kota Cirebon tahun 2011. Skripsi : Program Studi Ilmu Keperawatan STIKes Cirebon : 2011

7. Amran Y dkk, Pengaruh Tambahan Asupan Kalium Dari Diet Terhadap Penurunan Hipertensi Sistolik dan Diatolik Tingkat Sedang Pada Lanjut Usia. Artikel Penelitian: Universitas Islam Negeri Syarif Hasanuddin Jakarta;2010

8. Katno \& S.Pramono. Tingkat Manfaat dan Keamanan Tanaman Obat dan Obat Tradisional. Jogjakarta:Balai Penelitian Tanaman Obat Tawangmangu. Fakultas Farmasi, UGM: 2005

9. Zauhani Kusnul, Zainal Munir. Efek pemberian jus mentimun terhadap penurunan tekanan darah di UPT PSLU (Unit Pelayanan Terpadu, Pelayanan sosial lanjut Usia) Jombang.[diakses tanggal 23 Februari 2012]. Diunduh dari : www.journal.unipdu.ac.id

10. Soekirman et al. Hidup Sehat Gizi Seimbang dalam Siklus Kehidupan Manusia. Jakarta: PT. Gramedia; 2006

11. Notoatmodjo, Soekidjo . Metodologi Penelitian Kesehatan. Jakarta: Rineka Cipta : 2005

12. Canadian hypertension education program. 2009 CHEP recomendations for the management of hipertension. Canadian hypertension education program; [diakses tanggal 20 Februari 2012 ] diunduh dari: http:// www.hypertension.ca

13. Kuswardhani, Tuty. Penatalaksanaan Hipertensi Pada Lanjut Usia.[diakses tanggal 22 Februari 2012]. Diunduh dari: www.akademil.unsri.ac.id/download/journal

14. Arief Prahasta Soedarya, M.P. Argibisnis mentimun, Bandung:CVPustaka grafika;2009

15. Solanki.P. Nilai Gizi Mentimun, Jakarta:Rineka Cipta;2011 